\title{
Effect of Customers' Attitude, Involvement on Purchase Intention: Moderating Effect of Cause Related Marketing Campaigns
}

\author{
Farzana Riva ${ }^{1}$, Mohammad Rajib Uddin² \& Mohammad Rabiul Basher Rubel ${ }^{3}$ \\ ${ }^{1}$ Department of Marketing, Faculty of Business Studies, Bangladesh University of Professionals, Bangladesh \\ ${ }^{2}$ Department of Business Administration in General, Faculty of Business Studies, Bangladesh University of \\ Professionals, Bangladesh \\ ${ }^{3}$ Department of Management, Faculty of Business Studies, Bangladesh University of Professionals, Bangladesh \\ Correspondence: Mohammad Rabiul Basher Rubel, Department of Management, Faculty of Business Studies, \\ Bangladesh University of Professionals, Bangladesh. E-mail: asstprof sub@yahoo.com; \\ rabiul.basher@bup.edu.bd
}

Received: January 22, 2019

Accepted: February 25, 2019 Online Published: May 21, 2019

doi:10.5539/ijms.v11n2p75

URL: https://doi.org/10.5539/ijms.v11n2p75

\begin{abstract}
The current study considers customers' attitude, involvement and purchase intention of hotel customers with the moderating impact of cause related marketing campaigns in the context of Bangladesh. Partial Least Square (PLS) path modeling, a variance-based technique of SEM was used in the current study as the study tool. After testing the hypothesis on 305 customers it has been found positive significant influence of both customers' attitudes and involvement on purchase intention of hotel customers. Moreover, the current study used cause related marketing campaigns as a moderating variable between customers' attitude and involvement on purchase intention where both the hypothesis found insignificant. Therefore, from the literature review and the findings of the analysis the current study recommends future research to look for the moderating effect of cause related marketing campaigns of other customer perceptions in the link between attitude and involvement on purchase intention.
\end{abstract}

Keywords: CrM campaign, cause related marketing, customers' attitudes, involvement, purchase intention, Bangladesh

\section{Introduction}

Just ensuring the quality of the products or services does not guarantee the success in today's highly competitive business era. To ensure the success an alliance is necessary between a company and a cause for the mutual benefits (Koschate-Fischer, Stefan, \& Hoyer, 2012). CrM is the process to formulate and implement marketing practices that involves that the firm will contribute a specified portion of its revenue to a designated cause when customers are also engaged to generate revenue for the organizations (Varadarajan \& Menon, 1988). Basically, $\mathrm{CrM}$ can be defined as "the firms' contribution to a specified cause, where the amount of contribution is somehow dependent on customers' purchasing behavior that can create a win-win situation both for organization and cause as well as customer" (Chéron, Kohlbacher, \& Kusuma, 2012). CrM is an emerging concept among marketing practitioners and still in the infancy stage in the developing countries especially in India and its surrounding region (La Ferle, Kuber, \& Edwards, 2013). Due to the multiplier effect of Cause-related Marketing (CrM) on sales, nowadays CrM is being used by numerous companies as a factor that works on sales augment and that ultimately can help also to build a favorable brand and establish brand image. Nowadays, CrM are being used by most of the companies as a strategic tool and can be used to establish a favorable corporate and brand image in the minds of customers' (Chattananon, Lawley, Supparerkchaisaku, \& Leelayouthayothin, 2008) which can result in increased sales of a company's products and boost up the profits (Suki, 2013) and customers will have emotional attachment with those companies that make themselves involved with charities and good causes.

Notable numbers of researches are being carried out to find out the association between customers liking to CrM and purchase intention by using laboratory experiments and attitudinal surveys (Koschate-Fischer, Stefan, \& Hoyer, 2012). Moreover, customers can be benefited whenever they are participating in any CrM campaign by purchasing the products or services from the companies those are involved in CrM campaigns in terms of better value proposals (Robinson et al., 2012). CrM strategy can increase brand image, greater brand awareness as well 
as can resulted in favorable attitudes towards the brand that can ultimately result in increased purchase intention by the customers (Barone, Norman, \& Miyazaki, 2007; Lafferty, 2007) and customers' satisfaction can be increased with the products or services than the normal purchasing situation without CrM campaign (Luo \& Bhattacharya, 2006; Yoon, Gürhan - Canli, \& Schwarz, 2006).

As for an example, eBay's, Giving Works, this CrM planning helped to raise more than $\$ 500$ million for charities (givingworks.ebay.com, 2014). Nowadays corporate spending that is related with charitable sponsorships approaches is more than $\$ 18$ billion (Vanhamme, Lindgreen, Reast, \& Van Popering, 2012). Customers are interested to give reward to the corporations who are practicing good corporate behavior (Moosmayer, 2008). Many companies all around the globe have been devising many innovative ideas and programs to get the same result just like American Express in 1983. In the USA as well as in other developed countries, CrM campaigns have been using as a common marketing tool for more than 20 years (Kotler \& Keller, 2006). As example these things can come to the point of discussion that in 2009, Mirabella Beauty for every lipstick sold contributed $\$ 1$ to the City of Hope disease research and treatment center. Over the past decade and a half, numerous companies especially in developed countries have accepted CrM due to its increased benefits especially on sales (Liu, 2013). The popularity of CrM in USA seems that it would be accepted by other marketer without any further delay (Liston-Heyes \& Liu, 2013; Chen, Deshpande, \& Z Basil, 2011). Multiple numbers of researches have been carried out to find out the impact of CrM on customers' responses in developed countries like Canada and New Zealand to understand this emerging concept from different perspectives. But a very little work has done in the context of developing countries. With this conceptualization the current study is a little effort to find out the answer of these questions:

- Does Customers attitudes toward CrM have a positive impact on purchase intentions of hotel customers?

- Does Customers involvement with CrM have a positive impact on customer purchase intentions?

- What is the moderating effect of cause related marketing campaign while attitudes and involvement influencing the purchase intention?

Customers enjoy the participation with the CrM campaign, and it can produce better brand attitudes and can result in increased purchase intention (Liston-Heyes \& Liu, 2013). Recent researches on cause-related marketing mainly have been trying to focus on basic two areas: CrM from the perspective of company's and the impact of $\mathrm{CrM}$ on customers' behavior specially on consumption or purchase behavior and the impact of CrM on other Stakeholders' behavior as well as customers' responses (Roy \& Graeff, 2003). Larson, Flaherty, Zablah, Brown and Wiener (2008) shows that there is a link between cause-related marketing and sales forces performance. Overall, previous research has shown that cause-related marketing can positively influence customers' attitudes and purchase behavior (Arora \& Henderson, 2007; Chang, 2008; Haruvy \& Popkowski Leszczyc, 2009; Popkowski Leszczyc \& Rothkopf, 2010). However, there are many aspects still unexplored related with CrM that can either increase the effectiveness of $\mathrm{CrM}$ as a marketing tool or can increase the customers purchase intention for the products (Chéron, Kohlbach, \& Kusuma, 2012). Nowadays, CrM is being accepted as a valuable marketing tool (McWilliams, Siegel, \& Wright, 2006), in general and specially in Asian context (Chéron, Kohlbach, \& Kusuma, 2012). Customers' responses towards any organization can be influenced by the attitudes of customers' toward CrM (Galan-Ladero, Galera-Casquet, \& Wymer, 2013). CrM strategy can increase marketing performance in terms of sales as well as can be proved as "manipulative gimmicks" (Chang \& Cheng, 2015). Whenever any corporation involves itself with a disaster situation it can arouse more favorable responses from the customers' due to customers' perception regarding the disaster. There is some literature that found the moderating role of involvement for the effectiveness of cause related marketing (Grau \& Folse, 2007). Shabbir, Kaufmann, Ahmad and Qureshi (2010) found through a study in Pakistan that cause related marketing campaigns, brand awareness and image have an impact on customers' purchase intention specially in the developing countries. Cause related marketing campaign has impact on brand loyalty specifically for telecom whereas attitude, image and belief of the customers' serve as the mediator for brand loyalty (Rashid, Hamidizade, Esfidani, \& Matin, 2016).

\section{Literature Review}

Nowadays, CrM is a growing issue with the maximum growth than ever before. CrM has been used by more than $85 \%$ of the organizations as well as organization's corporate members found through a survey by the PMA (Promotion Marketing Association) and Gable Group (2000). Corporate social responsibility (CSR) is not a new concept among American corporations and has become increasingly popular in the developing and less developed countries (Kuo \& Rice, 2015). CrM, involves the activities of a company where the company is committed to give a certain percentage of its profit as a donation to a social cause or to a non-profit organization 
conditional to customers' responses (La Ferle, Kuber, \& Edwards, 2013). The pioneer of cause-related marketing categorized CrM among CSR as "Do Better by Doing Good" (Varandarajan \& Menon, 1988). By purchasing a product or service that is linked with social causes the customers can be assured that they are donating money for a social cause and getting mental satisfaction (Koschate-Fischer, Huber, \& Hoyer, 2016). Through practicing cause related marketing companies can increase customer satisfaction as well as staff satisfaction; can develop new capabilities and can identify new resources (Christofi, Leonidou, Vrontis, Kitchen, \& Papasolomou, 2015; Kim, \& Johnson, 2013). CrM can help to improve corporate image and brand reputation and, more specifically improve the companies market performance (Maier, Meyer, \& Steinbereithner, 2016) and give competitive advantage (Kumar, Rahman, Kazmi, \& Goyal, 2012). Customers' responses toward any organization can be influenced by cause related marketing (Ladero, Casquet, Amaro, \& Mendez, 2013).

\subsection{Customers' Attitude and Purchase Intention}

In November 2006, a survey had been conducted by the Cone Holiday Trend Tracker in Boston by collecting data from 1022 adults, and the result was like this: 6 out of 10 shoppers are interested to purchase from the retailers that support a social cause. CONE report (2007) found how customers' perception and attitudes toward cause-related marketing can increase or decrease the purchase intention of U.S customers. Today customers' can easily get huge amount of information within a second about the company, products, and prices. As a result of their increased awareness the number of factors that can influence the customers' responses towards any organization or products are also increasing (Vanhamme, Lindgreen, Reast, \& Van Popering, 2012). Just like several factors are involved in customers' responses cause-related marketing can influence customer responses. Whereas, customers' donation behavior is influenced by prosocial behavior theory (Müller, Fries, \& Gedenk, 2014) that has been identified as particularly relevant while explaining the appeal of cause related marketing (Sánchez Hernández, Gallardo Vázquez, \& Galán Ladero, 2013). CSR initiative in general and Cause related marketing in specific can have direct impact on purchase intention, repeat purchase intention and recommendation willingness (Vlachos, Tsamakos, Vrechopoulos, \& Avramidis, 2009; Walker, Kent, \& Vincent, 2010). After identifying the importance of these kinds of attributions, in terms of attitudinal response mechanism this study tried to find out that customers' attitudes towards cause related marketing initiative can have an impact on customers' purchase intention specifically travel intention of hotel customers. Based on the above rationale about attitudes and purchase intention this study develops the following hypothesis

Hypothesis1: Customers' positive attitude towards cause-related marketing is positively associated with purchase intention of hotel customers.

\subsection{Customers' Involvement and Purchase Intention}

In general involvement is understood as personal connection or personal relevance with a situation (Antil, 1984; Adkins, 2007) and it is highly related with customers' inherent attitudes, interest and needs (Zaichkowsky, 1985) The extent customers will be involved with the purchase situation as well as the amount of information they will process for purchasing largely depends on involvement (Bigné, Currás-Pérez, \& Aldás-Manzano, 2012). The cause that is relevant to the audience and circulated through an advertisement can increase the credibility of the organization. So, cause involvement increase the interest of the customers and this increased interest can develop positive attitudes toward the company and ultimately purchase intention (Fan \& Miao, 2012). According to the Elaboration Likelihood Model (ELM) involvement with the causes can have an influence how customers' process cause-related marketing messages and can determine their behavioral responses (Andrews, Luo, Fang, \& Aspara, 2014) whereas social cause has an association with the responses (Jung \& Yoon, 2012). A survey had been conducted by the 'Heart and Sold 'researcher Worthington Di Marzio in August 2001 among 752 customers in Australia and it found that more than one third of customers are interested to buy a company's offerings due to the association of a social cause that is important for the customers to some extent (Skarmeas \& Leonido, 2013). Customers' involvement can be expressed through multiple ways such as involvement with products, advertisements or purchase decisions (Zaichkowsky, 1994) and social causes. Few studies carried out to find the influence of cause involvement on purchase intention. So, with this conceptualization a hypothesis for this study can be developed as;

\section{Hypothesis2: Customers' involvement with the causes is positively related with purchase intention.}

\subsection{CrM Campaign as Moderator Between Involvement, Attitude and Purchase Intention}

$\mathrm{CrM}$ campaigns can be defined as a viable strategy that is used for the organizations of messages and promotional aspects related with a specific cause. And the main objectives can be to boost up the sales, to make the customers interested to donate for a cause and to enhance the reputation or images of the corporations or the brands (Hoek \& Gendall, 2008). Primarily the researchers tried to find out the customers' responses toward CrM 
and the main focus was to understand what is CrM campaign, how the CrM campaign or the element of CrM campaign can affect attitudes and purchase intention (Al-Dmour, Al-Madani, Alansari, Tarhini, \& Al-Dmour, 2016). The messages that are used to promote the causes and the CrM initiative have importance on customers' responses. Also, some customers respond more favorably toward the cause related marketing campaigns that is more immediate rather than future focus such as giving aid to the needy affected by natural disaster in a less developed country versus ongoing crisis such as giving aid to the victims of poverty. Several researches had been carried out to understand the impact of CrM campaign and the influence of CrM campaign on consumer responses (He, Zhu, Gouran, \& Kolo, 2016), no such significant research to date has examined how the moderating role of a CrM campaign combines with a customers' positive attitudes toward CrM and customers' involvement on purchase intention whereas perceived message quality of cause related marketing campaign had been studied as a moderator (Ponte \& Richey, 2014). So, two hypotheses can be developed for this study.

Hypothesis 3: Cause related marketing campaign moderates the relationship between customers' attitudes and purchase intention of hotel customers.

Hypothesis 4: Cause related marketing campaign moderates the relationship between customers' involvement and purchase intention of hotel customers.

\section{Methodology}

The current study was a correlational and cross-sectional study which employed the survey method to collect data at one point of time. Data were collected from the hotel customers of Dhaka and Chottogram division where more than 53\% hotels of Bangladesh are located (Bangladesh Tourism Board, 2017). Therefore, Dhaka and Chottogram were considered as sampling frame for the current study. The current research used a purposive judgmental sampling technique. The purposive sampling is confined to specific types of people who can specify the desired information, either because they are the only ones who have it or conform to some criteria set by researchers (Sekaran \& Bougie, 2010). For collecting the data smoothly, the current study distributed the questionnaire through drop-off and pick-up (DOPU) technique to the selected hotels. Owing to the absence of the supervisors, purposive judgmental sampling was employed whereas information center and customer care department of hotels conducted the survey.

A total of 700 questionnaires were distributed among the customers. Among these 700 questionnaires 325 questionnaires were returned where 305 (43.5\%) questionnaire were found usable for data analysis. Whereas, 20 questionnaires were found either blank or incomplete and consider unusable. In the context of Bangladesh, Rubel and Kee (2015) only had a 29 per cent response rate and found suitable results. Hence, the present response rate (40.6 per cent) was considered acceptable.

In the current study, four demographic characteristics, namely, gender, age, marital status, monthly income and were employed to group the respondents. Near about two-third of the respondents (65 per cent) were female. More than one-third of the respondents (45.5) were found age between 23 to 27 years. Over half of the respondents ( 54.75 per cent) were single. Near about one-third of the respondents' ( 42.2 per cent) monthly income were between Tk. 50000-Tk. 79000.

Table 1. Demographic profile of the respondents

\begin{tabular}{lll}
\hline Demographic Profile & Number of Respondents $(\mathrm{N}=305)$ & Valid Percentage $(\%)$ \\
\hline Gender & & \\
Male & 197 & 35 \\
Female & 108 & 65 \\
Age & & \\
18-22 years & 104 & 34 \\
23-27 years & 139 & 45.5 \\
28-32 years & 36 & 12 \\
32 years and above & 26 & 8.5 \\
Marital Status & & \\
Single & 167 & 54.75 \\
Married & 138 & 45.25 \\
Income & & \\
Less than 50000 & 101 & 33.3 \\
Tk. 50000-Tk. 79999 & 129 & 42.2 \\
Tk. 80000-Tk. 99999 & 37 & 12.0 \\
More than 110000 & 38 & 12.5 \\
\hline
\end{tabular}




\subsection{Measurement Instrument}

The constructs in this study were measured using 5-point Likert scales drawn and modified from previous literature. Customers' attitude toward CrM with four items resulted from the original items used by Ross, Patterson and Stutts (1992) and Kropp, Holden and Lavack (1999). Involvement with the cause was measured on a ten-item with semantic differential scale with alpha 0.91 adopted from the study of Zaichkowski (1994). CrM campaign was measured by using four items adapted from the study of (Shabbir, Kaufmann, Ahmad, \& Qureshi, 2010) with alpha value of .753. To measure the customer purchase intentions five items were adapted from the study of Hou, Du and $\mathrm{Li}$ (2008). To examine the proposed cause and effect relationship, partial least squares approach has been used that is a similar technique of multiple regression analysis (Hair, Ringle, \& Sarstedt, 2013).

\section{Analysis and Result}

\subsection{Measurement Model}

The measurement model has been examined through the convergent and discriminant validity. The extent to which the construct is with same or similar meaning has been examined through convergent validity that includes item/factor loading, average variance extracted (AVE), and composite reliability (CR) per Hair, Ringle and Sarstedt (2013). In accordance with the recommendation from established literature, the cut-off values of AVEs and CRs were 0.5 and 0.7, respectively. According to (Igbaria, Guimaraes, \& Davis, 1995), 0.5 was used as the cut-off value of factor loading that resulted in two items deletion from the customers' involvement with ten items $($ INVOL9 $=0.478)$ and $($ INVOL10 $=0.483)$. Table 1 shows the final individual item loadings, CRs, and AVEs of all the constructs.

Table 2. Result of measurement model

\begin{tabular}{lllll}
\hline Construct & Items & Loading & AVE & CR \\
\hline Attitude & ATTITU 1 & 0.731 & 0.623 & 0.868 \\
& ATTITU 2 & 0.834 & & \\
& ATTITU 3 & 0.818 & & \\
& ATTITU 4 & 0.771 & & 0.803 \\
CrM Campaign & CRM 1 & 0.743 & 0.507 & \\
& CRM 2 & 0.694 & & \\
Involvement & CRM 3 & 0.769 & & \\
& CRM 4 & 0.634 & & \\
& INVOL 1 & 0.683 & 0.509 & \\
& INVOL 2 & 0.825 & & \\
& INVOL 3 & 0.622 & & \\
& INVOL 4 & 0.559 & & \\
& INVOL 5 & 0.753 & & \\
& INVOL 6 & 0.683 & & \\
& INVOL 7 & 0.753 & & \\
& INVOL 8 & 0.788 & & \\
Purchase Intension & PI 1 & 0.843 & 0.561 & \\
& PI 2 & 0.769 & & \\
& PI 3 & 0.717 & & \\
& PI 4 & 0.695 & & \\
& PI 5 & 0.713 & & \\
\hline
\end{tabular}

Next discriminant validity has been measured to find out to what extent items are able to differentiate between constructs or to measure distinct concepts and it was evaluated with the comparison of the correlations between a construct and the square root of the AVEs for that construct (Fornell \& Larcker, 1981). For this study, the discriminant validity was found to be acceptable. 
Table 3. Result of measurement model

\begin{tabular}{lllll}
\hline Particulars & Attitude & CrM Campaign & Involvement & P Intention \\
\hline Attitude & $\mathbf{0 . 7 8 9}$ & & & \\
CrM Campaign & 0.297 & $\mathbf{0 . 7 1 2}$ & & \\
Involvement & 0.295 & 0.044 & $\mathbf{0 . 7 1 3}$ & \\
P Intention & 0.456 & 0.274 & 0.450 & $\mathbf{0 . 7 4 9}$ \\
\hline Mean & 3.52 & 3.54 & 4.51 & 3.681 \\
S. D & 0.757 & 0.742 & 0.897 & 0.892 \\
\hline
\end{tabular}

\subsection{Structural Model}

The structural model clarifies the associations of the constructs developed for the research model (Santhanamery \& Ramayah, 2015). The goodness of the theoretical model is established by the variance explicated $\left(\mathrm{R}^{2}\right)$ of the endogenous constructs and the significance of all path estimates (Chin, 2010). Both the $R^{2}$ and the path coefficients imply how well the data support the proposed model (Chin, 2010). In this study, the path coefficients of the structural model had been assessed and bootstrapping analysis was used to evaluate the statistical significance of the path coefficients. Bootstrap is a re-sampling technique, which entails repeated random sampling with replacement of the original sample to generate a bootstrap sample to get a standard error for hypotheses testing. Each path coefficient's significance can be retrieved through the bootstrapping techniques in which a significant path displaying the hypothesized direction empirically supports the proposed causal relationship and vice-versa (Hair et al., 2013).

This study explained $31.2 \%$ variance of purchase intention of customer by two dimensions such as attitude and involvement. Table 3 below shows the outcome of the structural model. Both dimensions found significant positive effect on purchase intention of personal care product such as, attitude $(\beta=0.301, p<0.01)$, involvement, $(\beta=0.354, p<0.01)$ Furthermore, the current study considered CrM campaign as moderator between attitude, involvement and purchase intention. CrM campaign found insignificant influence on attitude and purchase intention (-0.105) and involvement and purchase intention (-0.199). Thus, from the analysis of the result the moderating hypothesis showed not supported.

\section{Discussion}

Through this study, the researcher tried to build a conceptual framework that clarifies the relationship between customers' attitudes toward CrM, customers' involvement with the cause, CrM campaign and purchase intention. The researcher examined these effects from the perspective of hotel customers. This study found that customer' attitudes toward CrM has a significant influence on purchase intention of hotel customers just like the study findings of (Mohammed \& Rashid, 2012) that CrM as a part of CSR can influence the customers' purchase intention and behavior whenever customers will have favorable attitudes toward CrM. Moreover, customers' involvement impacts on purchase intention which resulted in that both attitude and involvement toward CrM can lead to purchase intention of hotel customers. CrM initiative can be benefited from involvement of the customers. Higher levels of involvement make the customers more interested to form attitudes that last long and behave according to the lasting attitudes (Rahman, Park, \& Chi, 2015). Beyond providing the rich description of the relationship among attitudes, involvement and purchase intention, this study tried to find out the moderating effect of cause related marketing campaign, but it was not significant in this study whereas as predictor the cause related marketing campaign has been found significant (Kuo \& Rice, 2015).

Table 4. Output of structural model

\begin{tabular}{lllll}
\hline Hypothesis for Direct Path & Std. Beta & Std. Error & t-Value & Decision \\
\hline Customer Attitude $>$ Purchase Intention & 0.301 & 0.046 & $6.609 * *$ & Supported \\
Customer Involvement $>$ Purchase Intention & 0.354 & 0.037 & $9.534 * *$ & Supported \\
\hline
\end{tabular}

Note. ${ }^{*} \mathrm{p}<.05, * * \mathrm{p}<.01$ (analyzed the direct relationship based on one-tailed).

\begin{tabular}{lllll}
\hline Moderator Path & & & & \\
\hline Hypothesis for Moderator & Std. Beta & Std. Error & $\mathrm{t}$-Value & Decision \\
\hline CrM Campaign $*$ Attitude $>$ Purchase Intention & -0.105 & 0.133 & 0.789 & Not Supported \\
CrM Campaign $*$ Involvement $>$ Purchase Intention & -0.199 & 0.048 & 4.120 & Not Supported \\
\hline
\end{tabular}

Note. ${ }^{*} \mathrm{p}<.05,{ }^{* *} \mathrm{p}<.01$ (analyzed the direct relationship based on one-tailed). 
First this study tried to find that customers attitude toward CrM and customers' involvement have direct and positive effects on purchase intention. When any hotel business wants to increase their sale in this highly competitive and growing market of hospitality and tourism services, the participants in this industry should work on the customers' attitude toward CrM and should focus on that kinds of causes with which customers are highly involved. The current study has some similarities of some previous studies whereas customers' value, involvement and attitudes toward cause-related marketing has an influence on purchase intention (Sarwar, Abbasi, \& Pervaiz, 2012). Values and attitudes can provide the motives that have an influence on shape customers' purchase intention and purchase behavior (Chen, Lobo, \& Rajendran, 2014).

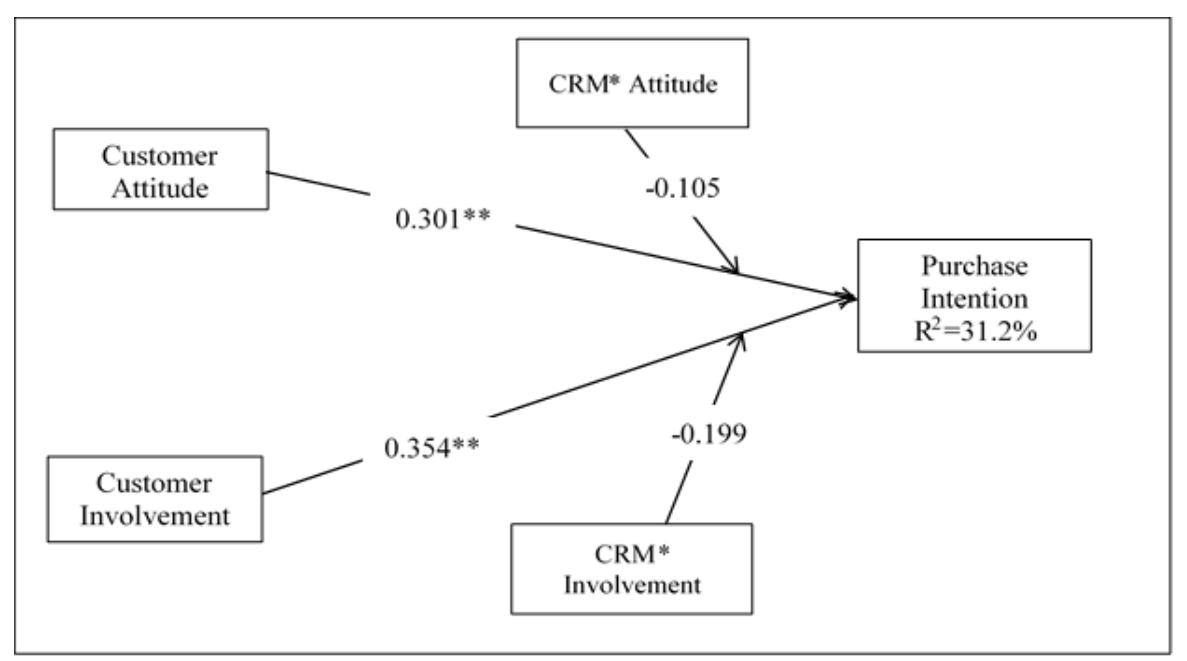

Figure 1. Structural model

It is not surprising that individuals who have positive attitudes towards the cause's related marketing are with the habits of giving at least 1 percent of their income to social causes or far any charity work. The customers with more predispositions for charitable giving are willing to be more supportive for the organizations practicing CrM though part of the prices go to the social causes (Andrews, Luo, Fang, \& Aspara, 2014). Marketers should select the causes for CrM that is related with the target customers' personality, lifestyle and values (Westberg \& Pope, 2014) Several studies have been carried out to prove that customers' involvement with the social cause can improve the brand's persuasive capacity in the CrM, and can positively moderate the cause related marketing's influence on customers' attitudes and behaviors (Elving, 2013). Cause related marketing campaigns can result in customers' attitude that can be favorable for the company. Cause related marketing campaign to help the customers to think more positively about the organization and can form favorable purchase intention. Proper organization of cause related marketing campaigns are closely associated with the favorable responses towards the sponsoring firm and the social causes (Myers, Kwon, \& Forsythe, 2012). CrM campaigns can give a medium for the customers to think about the organization and customers can support with small amount of money to charity that can also motivate the customers to think about to donate. So, it can be said that customers are more receptive to cause related marketing campaign when they are with favorable attitudes and involvement with the causes. Marketers can wisely use CrM campaign to boost up their performance because CrM campaign can increase their brand equity (Ashley \& Tuten, 2015). CrM campaign can favorably impact on customers' responses compared with a similar ad without a CrM component and CrM campaign is one of the easiest ways for any company to inform the customers about its philanthropic activities. So, it urges the necessity that CrM campaign will be studied further. Moreover, this study has the implications for specially NPO managers when they are interested to make partnership for a CrM campaign whenever customers have favorable attitudes toward the CrM campaign and customers are somehow involved with cause of the campaign. Studying CrM in the context of developing and less developed countries is comparatively new phenomena (Shamir, 2017). Though CrM strategy in its honeymoon stage in emerging nation so it can have a lower familiarity with the customers of this nation and as a result it may result into low acquaintances with CrM campaign. Just like the other studies $\mathrm{CrM}$ campaign can be a good predictor for customers purchase intention of hotel customers but as a moderator it is not significant whereas attitudes toward CrM and involvement with cause can have influence for purchase intention of hotel customers. 


\section{Limitations}

With remarkable contributions, the current study has some limitations also. First, this study concentrates on the purchase intention of hotel customers. Future research can focus on other industry that is using cause related marketing to attract the customers. Second this study studied the responses from the customers of Dhaka and Chottogram only. Future researcher can focus on other cities as well as other countries. Third this study verifies the hypotheses through cross sectional data. As a result, the current study cannot find the dynamic changes in the response of hotel customers. So, this study opens the door of future research to validate the results of this study with overcoming the limitation of the current study. This study can hope that the findings of this research will help managers, researchers, practitioners and policy makers, and will be used as reference for future research.

\section{References}

Adkins, S. (2007). Cause related marketing. Routledge. https://doi.org/10.4324/9780080490625

Al-Dmour, H., Al-Madani, S., Alansari, I., Tarhini, A., \& Al-Dmour, R. H. (2016). Factors affecting the effectiveness of cause-related marketing campaign: moderating effect of sponsor-cause congruence. International Journal of Marketing Studies, 8(5), 114-127. https://doi.org/10.5539/ijms.v8n5p114

Andrews, M., Luo, X., Fang, Z., \& Aspara, J. (2014). Cause marketing effectiveness and the moderating role of price discounts. Journal of Marketing, 78(6), 120-142. https://doi.org/10.1509/jm.14.0003

Antil, J. H. (1984). Conceptualization and operationalization of involvement. ACR North American Advances.

Arora, N., \& Henderson, T. (2007). Embedded premium promotion: Why it works and how to make it more effective. Marketing Science, 26(4), 514-531. https://doi.org/10.1287/mksc.1060.0247

Ashley, C., \& Tuten, T. (2015). Creative strategies in social media marketing: An exploratory study of branded social content and consumer engagement. Psychology \& Marketing, 32(1), 15-27. https://doi.org/10.1002/mar.20761

Bangladesh Tourism Board. (2017). Tourism Guide for the tourists in Bangladesh. Retrieved from http://www.mediafire.com/file/ion47ymod1hhd61/Tourist+Handbook.pdf

Barone, M. J., Norman, A. T. et al. (2007). Consumer response to retailer use of cause-related marketing: Is more fit better? Journal of Retailing, 83(4), 437-445. https://doi.org/10.1016/j.jretai.2007.03.006

Bigné, E., Currás-Pérez, R., \& Aldás-Manzano, J. (2012). Dual nature of cause-brand fit: Influence on corporate social responsibility consumer perception. European Journal of Marketing, 46(3/4), 575-594. https://doi.org/10.1108/03090561211202620

Chang, C. T. (2008). To donate or not to donate? Product characteristics and framing effects of cause - related marketing on consumer purchase behavior. Psychology \& Marketing, 25(12), 1089-1110. https://doi.org/10.1002/mar.20255

Chang, C. T., \& Cheng, Z. H. (2015). Tugging on heartstrings: shopping orientation, mindset, and consumer responses to cause-related marketing. Journal of Business Ethics, 127(2), 337-350. https://doi.org/10.1007/s10551-014-2048-4

Chattananon, A., Lawley, M. et al. (2008). Impacts of a Thai cause-related marketing program on corporate image. International Journal of Emerging Markets, 3(4), 348-363. https://doi.org/10.1108/17468800810906066

Chen, J., Lobo, A., \& Rajendran, N. (2014). Drivers of organic food purchase intentions in mainland C hina-evaluating potential customers' attitudes, demographics and segmentation. International Journal of Consumer Studies, 38(4), 346-356. https://doi.org/10.1111/ijcs.12095

Chen, S., Deshpande, S., \& Z Basil, D. (2011). Influence of Fit on Crm: Moderating Effects of Collectivism and Awareness. ACR Asia-Pacific Advances, 9, 282-289.

Chéron, E., Kohlbacher, F., \& Kusuma, K. (2012). The effects of brand-cause fit and campaign duration on consumer perception of cause-related marketing in Japan. Journal of Consumer Marketing, 29(5), 357-368. https://doi.org/10.1108/07363761211247479

Chin, W. W. (2010). How to write up and report PLS analyses. In Handbook of partial least squares (pp. 655-690). Springer, Berlin, Heidelberg. https://doi.org/10.1007/978-3-540-32827-8_29

Christofi, M., Leonidou, E., Vrontis, D., Kitchen, P., \& Papasolomou, I. (2015). Innovation and cause-related marketing success: a conceptual framework and propositions. Journal of Services Marketing, 29(5), 
354-366. https://doi.org/10.1108/JSM-04-2014-0114

Cone. (2007). Research Report - 2007: Cone Cause Evolution \& Environmental Survey. Retrieved June 15, 2018, from http://www.coneinc.com/content2012

Elving, W. J. (2013). Scepticism and corporate social responsibility communications: the influence of fit and $\begin{array}{llll}\text { reputation. Journal of Marketing } & \text { Communications, 19(4), } 297-292 .\end{array}$ https://doi.org/10.1080/13527266.2011.631569

Fan, Y. W., \& Miao, Y. F. (2012). Effect of electronic word-of-mouth on consumer purchase intention: The perspective of gender differences. International Journal of Electronic Business Management, 10(3), $175-180$.

Fornell, C., \& Larcker, D. F. (1981). Structural equation models with unobservable variables and measurement error: Algebra and statistics. Journal of Marketing Research, 382-388. https://doi.org/10.2307/3150980

Galan-Ladero, M. M., Galera-Casquet, C., \& Wymer, W. (2013). Attitudes towards cause-related marketing: determinants of satisfaction and loyalty. International Review on Public and Nonprofit Marketing, 10(3), 253-269. https://doi.org/10.1007/s12208-013-0103-y

Grau, S. L., \& Folse, J. A. G. (2007). Cause-related marketing (CRM): The influence of donation proximity and message-framing cues on the less-involved consumer. Journal of Advertising, 36(4), 19-33. https://doi.org/10.2753/JOA0091-3367360402

Hair, J. F., Ringle, C. M., \& Sarstedt, M. (2013). Partial least squares structural equation modeling: Rigorous applications, better results and higher acceptance. Long Range Planning, 46(1-2), 1-12. https://doi.org/10.1016/j.lrp.2013.01.001

Haruvy, E., \& Leszczyc, P. T. P. (2009). Bidder motives in cause-related auctions. International Journal of Research in Marketing, 26(4), 324-331. https://doi.org/10.1016/j.ijresmar.2009.07.001

He, H., Zhu, W., Gouran, D., \& Kolo, O. (2016). Moral identity centrality and cause-related marketing: the moderating effects of brand social responsibility image and emotional brand attachment. European Journal of Marketing, 50(1/2), 236-259. https://doi.org/10.1108/EJM-10-2014-0613

Hoek, J., \& Gendall, P. (2008). An analysis of consumers' responses to cause related marketing. Journal of Nonprofit \& Public Sector Marketing, 20(2), 283-297. https://doi.org/10.1080/10495140802224977

Hou, J., Du, L., \& Li, J. (2008). Cause's attributes influencing consumer's purchasing intention: Empirical evidence from China. Asia Pacific Journal of Marketing and Logistics, 20(4), 363-380. https://doi.org/10.1108/13555850810909704

Igbaria, M., Guimaraes, T., \& Davis, G. B. (1995). Testing the determinants of microcomputer usage via a structural equation model. Journal of Management Information Systems, 11(4), 87-114. https://doi.org/10.1080/07421222.1995.11518061

Jung, H. S., \& Yoon, H. H. (2012). Why do satisfied customers switch? Focus on the restaurant patron variety-seeking orientation and purchase decision involvement. International Journal of Hospitality Management, 31(3), 875-884. https://doi.org/10.1016/j.ijhm.2011.10.006

Kim, J. E., \& Johnson, K. K. (2013). The impact of moral emotions on cause-related marketing campaigns: A cross-cultural examination. Journal of Business Ethics, 112(1), 79-90. https://doi.org/10.1007/s10551-012-1233-6

Koschate-Fischer, N., Huber, I. V., \& Hoyer, W. D. (2016). When will price increases associated with company donations to charity be perceived as fair? Journal of the Academy of Marketing Science, 44(5), 608-626. https://doi.org/10.1007/s11747-015-0454-5

Koschate-Fischer, N., Stefan, I. V. et al. (2012). Willingness to pay for cause-related marketing: The impact of donation amount and moderating effects. Journal of Marketing Research, 49(6), 910-927. https://doi.org/10.1509/jmr.10.0511

Kotler, P., \& Keller, K. (2006). Marketing Management 12e. Pearson Prentice Hall, Upple Saddle River, New Jersey.

Kropp, F., Holden, S. J., \& Lavack, A. M. (1999). Cause-related marketing and values in Australia. International Journal of Nonprofit and Voluntary Sector Marketing, 4(1), 69-80. https://doi.org/10.1002/nvsm.57 
Kumar, V., Rahman, Z., Kazmi, A. A., \& Goyal, P. (2012). Evolution of sustainability as marketing strategy: Beginning of new era. Procedia-Social and Behavioral Sciences, 37, 482-489. https://doi.org/10.1016/j.sbspro.2012.03.313

Kuo, A., \& Rice, D. H. (2015). The impact of perceptual congruence on the effectiveness of cause - related marketing campaigns. Journal of Consumer Psychology, 25(1), 78-88. https://doi.org/10.1016/j.jcps.2014.06.002

La Ferle, C., Kuber, G., \& Edwards, S. M. (2013). Factors impacting responses to cause-related marketing in India and the United States: Novelty, altruistic motives, and company origin. Journal of Business Research, 66(3), 364-373. https://doi.org/10.1016/j.jbusres.2011.08.017

Ladero, M., Casquet, C. G., Amaro, V. V., \& Mendez, M. (2013). Sustainable, socially responsible business: the cause-related marketing case. A review of the conceptual framework. Journal of Security \& Sustainability Issues, 2(4). https://doi.org/10.9770/jssi.2013.2.4(4)

Lafferty, B. A. (2007). The relevance of fit in a cause-brand alliance when consumers evaluate corporate credibility. Journal of Business Research, 60(5): 447-453. https://doi.org/10.1016/j.jbusres.2006.09.030

Larson, B. V., Flaherty, K. E., Zablah, A. R., Brown, T. J., \& Wiener, J. L. (2008). Linking cause-related marketing to sales force responses and performance in a direct selling context. Journal of the Academy of Marketing Science, 36(2), 271-277. https://doi.org/10.1007/s11747-007-0056-y

Leszczyc, P. T. P., \& Rothkopf, M. H. (2010). Charitable motives and bidding in charity auctions. Management Science, 56(3), 399-413. https://doi.org/10.1287/mnsc. 1090.1120

Liston-Heyes, C. \& G. Liu (2013). A study of non-profit organisations in cause-related marketing: Stakeholder concerns and safeguarding strategies. European Journal of Marketing, 47(11/12): 1954-1974. https://doi.org/10.1108/EJM-03-2012-0142

Liu, G. (2013). Impacts of instrumental versus relational centered logic on cause-related marketing decision making. Journal of business ethics, 113(2): 243-263. https://doi.org/10.1007/s10551-012-1292-8

Luo, X. \& C. B. Bhattacharya (2006). Corporate social responsibility, customer satisfaction, and market value. Journal of marketing, 70(4): 1-18. https://doi.org/10.1509/jmkg.70.4.001

Maier, F., Meyer, M., \& Steinbereithner, M. (2016). Nonprofit organizations becoming business-like: A systematic review. Nonprofit and Voluntary Sector Quarterly, 45(1), 64-86. https://doi.org/10.1177/0899764014561796

McWilliams, A., Siegel, D. S., \& Wright, P. M. (2006). Corporate social responsibility: Strategic implications. Journal of management studies, 43(1), 1-18. https://doi.org/10.1111/j.1467-6486.2006.00580.x

Mohammed, A. A., \& Rashid, B. (2012). Customer Relationship Management (CRM) in Hotel Industry: A framework proposal on the relationship among CRM dimensions, Marketing Capabilities, and Hotel performance. International Review of Management and Marketing, 2(4), 220-230.

Moosmayer, D. C. \& A. Fuljahn (2010). Consumer perceptions of cause related marketing campaigns. Journal of Consumer Marketing, 27(6): 543-549. https://doi.org/10.1108/07363761011078280

Müller, S. S., Fries, A. J., \& Gedenk, K. (2014). How much to give? The effect of donation size on tactical and strategic success in cause-related marketing. International Journal of Research in Marketing, 31(2), 178-191. https://doi.org/10.1016/j.jiresmar.2013.09.005

Myers, B., Kwon, W. S., \& Forsythe, S. (2012). Creating effective cause-related marketing campaigns: The role of cause-brand fit, campaign news source, and perceived motivations. Clothing and Textiles Research Journal, 30(3), 167-182. https://doi.org/10.1177/0887302X12452339

Patel, J. D., Gadhavi, D. D., \& Shukla, Y. S. (2017). Consumers' responses to cause related marketing: moderating influence of cause involvement and skepticism on attitude and purchase intention. International Review on Public and Nonprofit Marketing, 14(1), 1-18. https://doi.org/10.1007/s12208-016-0151-1

Petty, R. E., Cacioppo, J. T., \& Schumann, D. (1983). Central and peripheral routes to advertising effectiveness: The moderating role of involvement. Journal of Consumer Research, 10(2), 135-146. https://doi.org/10.1086/208954

PMA (Promotion Marketing Association) and Gable Group. (2000). Survey of Cause Marketing. Retrieved 
March, 2018, from http://www pmalink.org/members/causemarketing2000/default.asp

Ponte, S., \& Richey, L. A. (2014). Buying into development? Brand Aid forms of cause-related marketing. Third World Quarterly, 35(1), 65-87. https://doi.org/10.1080/01436597.2014.868985

Rahman, I., Park, J., \& Chi, C. G. Q. (2015). Consequences of "green washing" Consumers' reactions to hotels' green initiatives. International Journal of Contemporary Hospitality Management, 27(6), 1054-1081. https://doi.org/10.1108/IJCHM-04-2014-0202

Rashid, A. A., Hamidizade, A., Esfidani, M. R., \& Matin, H. Z. (2016). The effect of cause-related marketing on the consumer purchase intention: focusing on the meditating variables (studied on clients of Ghalamchi educational services). International Journal of Business Forecasting and Marketing Intelligence, 2(3), 233-247. https://doi.org/10.1504/IJBFMI.2016.078605

Robinson, S. R., Irmak, C., \& Jayachandran, S. (2012). Choice of Cause in Cause-Related Marketing. Journal of Marketing, 76(4), 126-139. https://doi.org/10.1509/jm.09.0589

Ross, J. K., Patterson, L. T., \& Stutts, M. A. (1992). Consumer perceptions of organizations that use cause-related marketing. Journal of the Academy of Marketing Science, 20(1), 93-97. https://doi.org/10.1007/BF02723480

Roy, D. P., \& Graeff, T. R. (2003). Consumer attitudes toward cause-related marketing activities in professional sports. Sport Marketing Quarterly, 12(3), 163-172.

Rubel, M. R. B., \& Kee, D. M. H. (2015). Perceived fairness of performance appraisal, promotion opportunity and nurses turnover intention: The role of organizational commitment. Asian Social Science, 11(9), 183. https://doi.org/10.5539/ass.v11n9p183

Sánchez Hernández, M. I., Gallardo Vázquez, D., \& Galán Ladero, M. (2013, September). Discovering how Social Responsibility certification can help rural tourism to succeed (pp. 4-7). In Comunicación presentada en The International Conference on Rural Tourism-ORTE.

Santhanamery, T., \& Ramayah, T. (2015). Understanding the effect of demographic and personality traits on the e-filing continuance usage intention in Malaysia. Global Business Review, 16(1), 1-20. https://doi.org/10.1177/0972150914553459

Sarwar, M. Z., Abbasi, K. S., \& Pervaiz, S. (2012). The effect of customer trust on customer loyalty and customer retention: A moderating role of cause related marketing. Global Journal of Management and Business Research, 12(6), 1-10.

Sekaran, U., \& Bougie, R. (2010). Theoretical framework in theoretical framework and hypothesis development. Research methods for business: A skill building approach, 80.

Shabbir, S., Kaufmann, H. R., Ahmad, I., \& Qureshi, I. M. (2010). Cause related marketing campaigns and consumer purchase intentions: The mediating role of brand awareness and corporate image. African Journal of Business Management, 4(6), 1229-1235.

Shamir, R. (2017). Between self-regulation and the Alien Tort Claims Act: On the contested concept of corporate social responsibility. In Crime and Regulation (pp. 155-183). Routledge. https://doi.org/10.4324/9781351126816-6

Shao, C. Y., Baker, J. A., \& Wagner, J. (2004). The effects of appropriateness of service contact personnel dress on customer expectations of service quality and purchase intention: The moderating influences of involvement and gender. Journal of Business Research, 57(10), 1164-1176. https://doi.org/10.1016/S0148-2963(02)00326-0

Shrikanth, R., \& Raju, D. S. N. (2012). Contemporary green marketing-brief reference to Indian scenario. International Journal of Social Sciences \& Interdisciplinary Research, 1(1), 26-39.

Skarmeas, D., \& Leonidou, C. N. (2013). When consumers doubt, watch out! The role of CSR skepticism. Journal of Business Research, 66(10), 1831-1838. https://doi.org/10.1016/j.jbusres.2013.02.004

Suki, N. M. (2013). Green Awareness Effects on Consumers' purchasing Decision: Some Insights from Malaysia. International Journal of Asia-Pacific Studies, 9(2), 49-63.

Vanhamme, J., Lindgreen, A., Reast, J., \& Van Popering, N. (2012). To do well by doing good: Improving corporate image through cause-related marketing. Journal of Business Ethics, 109(3), 259-274. https://doi.org/10.1007/s10551-011-1134-0 
Varadarajan, P. R., \& Menon, A. (1988). Cause-related marketing: A coalignment of marketing strategy and corporate philanthropy. The Journal of Marketing, 58-74. https://doi.org/10.2307/1251450

Vlachos, P. A., Tsamakos, A., Vrechopoulos, A. P., \& Avramidis, P. K. (2009). Corporate social responsibility: attributions, loyalty, and the mediating role of trust. Journal of the Academy of Marketing Science, 37(2), 170-180. https://doi.org/10.1007/s11747-008-0117-x

Walker, M., Kent, A., \& Vincent, J. (2010). Communicating socially responsible initiatives: An analysis of US professional teams. Sport Marketing Quarterly, 19(4), 187-195.

Westberg, K., \& Pope, N. (2014). Building brand equity with cause-related marketing: A comparison with sponsorship and sales promotion. Journal of Marketing Communications, 20(6), 419-437. https://doi.org/10.1080/13527266.2012.723025

Yoon, Y., Gürhan - Canli, Z. et al. (2006). The effect of corporate social responsibility (CSR) activities on companies with bad reputations. Journal of Consumer Psychology, 16(4), 377-390. https://doi.org/10.1207/s15327663jcp1604_9

Zaichkowsky, J. L. (1985). Measuring the involvement construct. Journal of Consumer Research, 12(3), 341-352. https://doi.org/10.1086/208520

Zaichkowsky, J. L. (1994). The personal involvement inventory: Reduction, revision, and application to advertising. Journal of Advertising, 23(4), 59-70. https://doi.org/10.1080/00913367.1943.10673459

\section{Copyrights}

Copyright for this article is retained by the author, with first publication rights granted to the journal.

This is an open-access article distributed under the terms and conditions of the Creative Commons Attribution license (http://creativecommons.org/licenses/by/4.0/). 